\title{
Estimation of Reference Emission and Absorption Levels in Benin's Protected Areas
}

\author{
Ismaïla Toko Imorou ${ }^{1}$, Yaya Issifou Moumouni', Djaouga Mama ${ }^{1}$, Arouna Ousséni², \\ Zakari Soufouyane1, Matilo Orou Augustin'3, Satoguina Honorat4, Yabi Ibouraïma5, \\ Djego Julien ${ }^{6}$, Thomas Omer ${ }^{1}$, Houssou Christophe ${ }^{5}$
}

\author{
${ }^{1}$ Laboratory of Cartography (LaCarto), Institute of Geography, Land Management and Environment (IGATE), University of \\ Abomey-Calavi (UAC), Abomey-Calavi, Benin \\ ${ }^{2}$ Laboratory of Geosciences, Environment and Applications, National School of Public Works, National University of Sciences, \\ Technologies, Engineering and Mathematics (UNSTIM), Abomey, Benin \\ ${ }^{3}$ Center of Study and Forest Research (CERF), General Directorate of Water, Forests and Hunting (DGEFC), Cotonou, Benin \\ ${ }^{4}$ National Fund for Scientific Research and Technological Innovation (FNRSIT), Cotonou, Benin \\ ${ }^{5}$ Pierre Pagney Laboratory, Climate, Water, Ecosystem and Development (LACEEDE), Department of Geography and Spatial \\ Planning (DGAT), University of Abomey-Calavi (UAC), Abomey-Calavi, Benin \\ ${ }^{6}$ Laboratory of Applied Ecology (LEA), Faculty of Agronomic Sciences (FSA), University of Abomey-Calavi (UAC), \\ Abomey-Calavi, Benin \\ Email: issifoumyaya@gmail.com,tokismael@gmail.com
}

How to cite this paper: Toko Imorou, I. Issifou Moumouni, Y., Mama, D., Ousséni, A., Soufouyane, Z., Augustin, M. O., Honorat, S., Ibouraïma, Y., Julien, D., Omer, T., \& Christophe, H. (2021) Estimation of Reference Emission and Absorption Levels in Benin's Protected Areas. Low Carbon Economy, 12, 117-136. https://doi.org/10.4236/lce.2021.123006

Received: August 14, 2021

Accepted: September 27, 2021

Published: September 30, 2021

Copyright ( 2021 by author(s) and Scientific Research Publishing Inc. This work is licensed under the Creative Commons Attribution International License (CC BY 4.0).

http://creativecommons.org/licenses/by/4.0/ (c) (i) Open Access

\begin{abstract}
For the implementation of the REDD+ mechanism, the UNFCCC, through decision $12 / \mathrm{CP} 17$, invites countries to develop certain tools to estimate reference emission levels for forests. With this in mind, reference emission and absorption levels were estimated in five protected areas in Benin. To achieve this, two different datasets were used, namely: in situ data from the field collection campaign carried out in 2018, especially from the national forest inventory of 2007 and land use data from 2000 to 2018. In accordance with the 2006 IPCC Good Practice Guidance on Greenhouse Gas Inventories, the calculation of historical emissions from deforestation and degradation is done by multiplying Activity Data (AD) by Emission Factors (EF). The analysis of the results shows that at the national level, the annual deforestation rate in protected areas is $0.34 \%$ (2091 ha/year), compared to $1.09 \%$ ( $3153 \mathrm{ha} /$ year) for the annual degradation rate. Overall, carbon emissions amount to $166.65 \mathrm{Mt}$.eq$\mathrm{CO}_{2} /$ ha, or $16.67 \mathrm{Mt}$.eq- $\mathrm{CO}_{2} /$ ha/year, compared to baseline removals of about $1.14 \mathrm{Mt}$.eq- $\mathrm{CO}_{2} / \mathrm{ha}$, or $0.11 \mathrm{Mt}$.eq- $\mathrm{CO}_{2} / \mathrm{ha} /$ year in the protected areas covered by this research. Annual emissions of $0.67 \mathrm{Mt}$.eq- $\mathrm{CO}_{2} /$ ha/year from methane are also noted, compared to $0.056 \mathrm{Mt}$.eq- $\mathrm{CO}_{2} / \mathrm{ha} / \mathrm{year}$ from nitrous oxide. Therefore, It is clear that actions to mitigate GHG emissions must be undertaken directly in Benin's protected areas in order to strengthen forest carbon stocks.
\end{abstract}




\section{Keywords}

Benin, Protected Areas, Reference Emission Level, Deforestation, REDD+

\section{Introduction}

The impact of human activities on the environment has taken on an unprecedented magnitude for just over a century leading to significant changes in the biosphere. By 2050, a global warming estimated at about $2.5^{\circ} \mathrm{C}$ and a significant change in climate parameters are expected (IPCC, 2019). The significant increase of greenhouse gases in the atmosphere, caused by industrial emissions and deforestation, would be partly responsible for this global warming (Herzog, 2005).

Forests are important in the global carbon cycle because they store large amounts of carbon in the vegetation and soil. They exchange carbon with the atmosphere through photosynthesis and respiration and are atmospheric carbon sinks (net absorption of $\mathrm{CO}_{2}$ from the atmosphere) when well conserved and managed, they become sources of atmospheric carbon when disturbed by human or natural causes (wildfires, logging under poor harvesting procedures, cultivation clearing and burning for conversion of the forest to other uses) (Issifou Moumouni, 2020; Ago, 2016; Yabi et al., 2016). Tropical forests in particular are considered exceptional reservoirs of carbon and biodiversity and are at the heart of international issues on climate change (Marquant et al., 2015).

Aware of the seriousness of the risk and its implications on people's lives, the United Nations established an International Panel on Climate Change (IPCC) in 1988 and 1992. The United Nations Framework Convention on Climate Change (UNFCCC) was adopted during the Earth Summit in Rio de Janeiro by 154 countries. It was not until 2010, during the Conference of the Parties (COP-16) held in Cancún, that the legal act of the greenhouse gas emission reduction mechanism (REDD) was formally born in its larger scale version (REDD+), which integrates sustainable forest management, plantations and forest conservation. This REDD+ program should help develop a "green economy" by making climatefriendly investments more attractive (Molto, 2012). It should also allow states that protect their forests to access the carbon market. The avoidance of forest destruction or degradation generates a "carbon credit" and the sale of this credit on the carbon market offsets the economic loss from protecting the forest. At the Paris Climate Change Conference (COP21) in December 2015, 195 countries adopted the first-ever international and universal climate agreement that set out a global action plan limiting the increase in global warming to below $2^{\circ} \mathrm{C}$. One of the key outcomes is the creation of an Enhanced Transparency Framework (ETF), which aimed to build confidence in countries' contributions and progress (FAO, 2016). One of the elements that countries must develop to participate in REDD+ is the establishment of a forest reference emission level and/or forest reference level (FREL/FRL). The UNFCCC has defined the reference emission 
level for forests as a benchmark for assessing each country's performance in implementing REDD+ activities. Also, for the implementation of the REDD+ mechanism, the UNFCCC, through decision 12/CP17, invites countries to develop certain tools, including reference levels for forests.

The UNFCCC decisions on REDD+ encourage developing countries to contribute to mitigation actions by undertaking voluntary activities that reduce Greenhouse Gas (GHG) emissions and enhance carbon sinks in the forest sector. The five activities included in the REDD+ mechanism are: reducing emissions from deforestation; reducing emissions from forest degradation; conserving carbon stocks; sustainable management of forests; and enhancing forest carbon stocks. In response to the challenges of deforestation and climate change, Benin has voluntarily engaged in the process of reducing greenhouse gas emissions from deforestation and forest degradation for several years, in order to fully meet the objectives of the REDD+ mechanism. According to (Issifou Moumouni, 2020), despite these commendable efforts to reduce deforestation and forest degradation, the level of consideration of REDD+ in Benin is still low because it has not implemented its national REDD+ strategy (CEDEAO, 2015). In the sub-region, Benin is placed in the category of countries with high potential for REDD+ readiness because it has sometimes separately developed policies, strategies and approaches that can be easily leveraged (CEDEAO, 2015).

In Benin, 58 forest massifs have been classified, representing nearly $25 \%$ of the national territory. This statistic has remained unchanged since the last report on Benin's biodiversity in 2016. However, depending on their richness in wildlife and valuable forest species, it must be admitted that the various protected areas thus classified have been assigned to specific development modes. The national parks benefit from a good conservation program. The classified forests and reforestation perimeters (except for the classified forest of Lama) undergo a very high degree of fragmentation that does not favor the conservation of biodiversity. However, it should be noted that the successes achieved in the management of protected areas in Benin are explained by the fact that these areas have participatory management plans implemented by specific management units, many of which are currently being updated in the country. As recommended by the World Commission on Protected Areas (WCPA) of the International Union for Conservation of Nature (IUCN), all of a country's protected areas or network of national protected areas should be representative of all existing ecosystems. While the savannahs are well represented in Benin's protected area system, the dense forests of southern Benin are poorly represented and other remarkable ecosystems such as the vast majority of inselbergs in central Benin and the Atacora chain are absent. An important fraction of the biodiversity is thus unprotected by the network of state protected areas of Benin.

Mitigating climate change will be both costly and difficult, but the costs and complexity associated with this challenge pale in comparison to the risks and costs that will inevitably accompany failure to take decisive action. In order to 
fully understand the mitigation potential of the agriculture, forestry and other land use (AFOLU) sector, it is necessary to estimate the greenhouse gases from deforestation and forest degradation in Benin's protected areas (Figure $1)$.

The estimation of reference emission and absorption levels in Benin's protected areas could serve as a basis for evaluating its efforts under REDD+. This article thus constitutes a contribution to results-based payments and especially to ensuring the coherence of sectoral policies and good governance of forest resources.

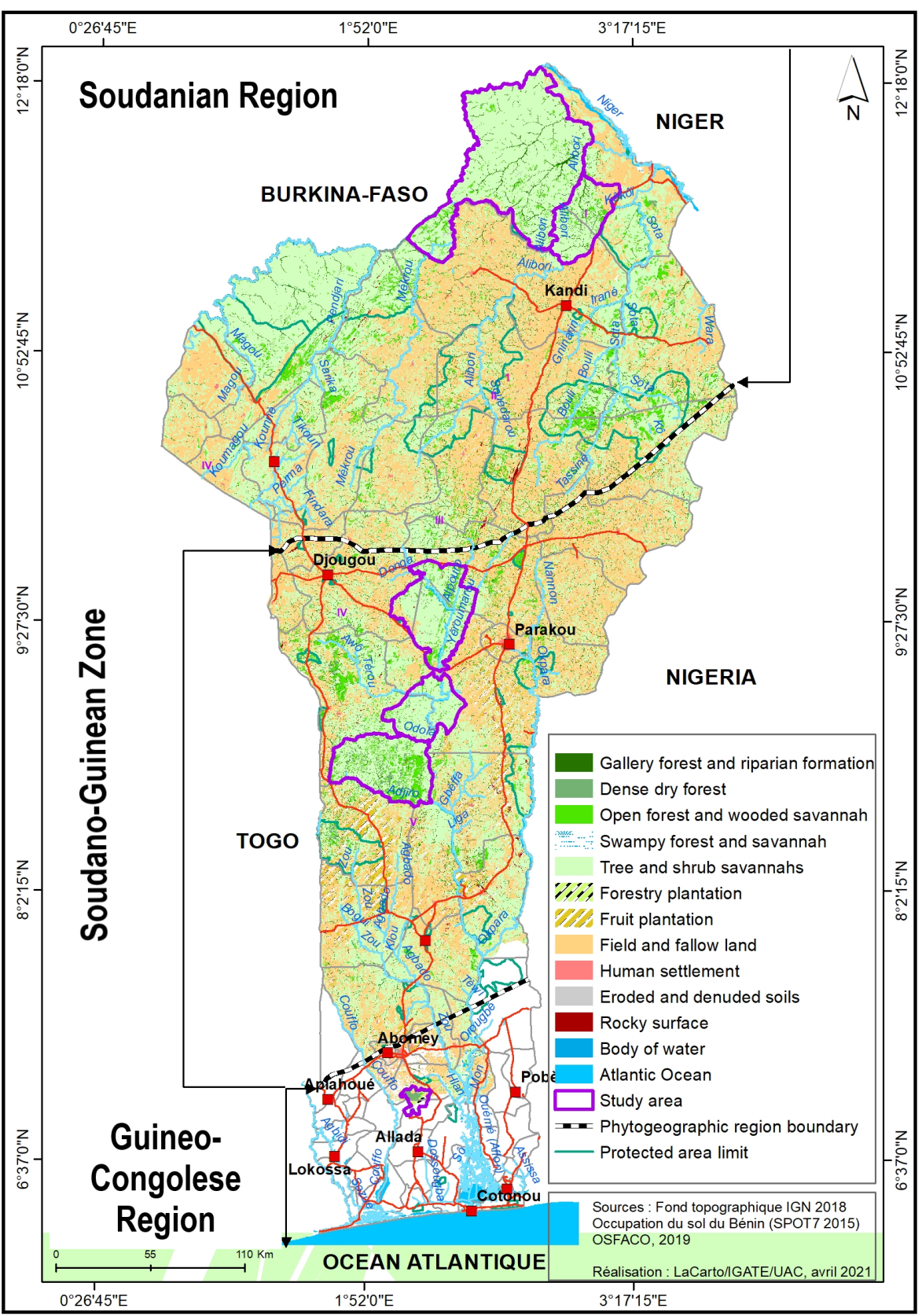

Figure 1. Location of protected areas studied. 


\section{Methodological Approach}

\subsection{Data Used}

Two different datasets were used to estimate the baseline emission level from forests due to deforestation:

- In situ data (forest inventory), which allowed the estimation of emission factors (carbon stock in $\mathrm{CO}_{2}$ equivalent).

- The land use maps of 2000 and 2018 from which activity data were calculated.

The data collected in situ come from the field collection campaign conducted in 2018 for all protected areas in the period from November to December and especially from the national forest inventory of 2007. It is from these data that the emission factors were determined.

Speaking of the land use data of 2000 and 2018 from which the activity data were calculated, they come from the digital processing work of Landsat TM satellite images of 2000 and OLI-TIRS, 2018.

\subsection{Choice of Reference Period}

Numerous cartographic data on land use have existed in Benin since 1975. Unfortunately, these data are often fragmented.

The year 2000 was chosen as the reference year because it is a point of convergence for the vast majority of cartographic products (CENATEL, 2013; IFN, 2007), etc. relating to forest area and land use in Benin. The year 2018 was chosen because it is very close to the reference year chosen by Benin for its Nationally Determined Expected Contribution (NDEF-2015) under the United Nations Framework Convention on Climate Change (UNFCCC). In September 2015, Benin submitted its INDC in advance of COP21 (21st Conference of the Parties, Paris, 2015). Then, in accordance with paragraph 22 of decision 1/COP.21 of the Paris Agreement, on October 31, 2016, Benin submitted its Nationally Determined Contribution (NDC) by updating its NDC.

This choice is also justified by the availability and consistency of satellite data and also in order to be in harmony with REDD+ investment projects at the sub-regional level that consider the period (2000-2030) a reference period (Issifou Moumouni, 2020). It is also appropriate to analyze historical data over a period that will better justify future deforestation trends with perceptible arguments on the ground.

\subsection{Method of Data Processing and Analysis}

The methods for determining activity data and emission factors are the primary approach to data processing and analysis.

\subsubsection{Method for Determining Activity Data (AD)}

The thresholds chosen to establish the national definition of forest may influence the assessment of forest area, the estimation of forest change, and the identifica- 
tion of contextually appropriate REDD+ activities for implementation. In this research, forest is defined as land between 0.05 and 1.0 hectare with trees that cover more than 10 - 30 percent of the area (or have an equivalent stand density) and that can reach a minimum height of 2 - 5 meters in situ at maturity (GIEC, 2006).

The (GIEC, 2006) guidelines describe three different approaches to representing activity data, i.e., the change in area of different land categories.

Approach 3 provides spatially explicit observations of land use categories and conversions, which can detect trends occurring at specific locations and/or using gridded maps, such as those obtained from satellite imagery, derived from wall-towall interpretation mapping techniques. Under a REDD mechanism, land-use change will need to be identifiable and traceable in the future. Thus, Approach 3 is the only approach that meets this objective. This approach was therefore used in this research.

The activity data correspond to the areas (ha/year) transiting from one land use class to another during the period of interest. The transitions of interest for the assessment of GHG emissions are those related to deforestation and forest degradation. In contrast, transitions related to natural recovery and land cover improvements are considered for the estimation of GHG removals.

Before proceeding with the actual analysis, the nomenclature used underwent a rearrangement by aggregating the land use units into three broad land use categories that are: forest land (FGFR, FD, FCSB, SASa, FSM), cropland (PT, CJ), and other land (PE, HA, SR, SED) to remain consistent with the IPCC recommendations for deforestation emissions inventory.

The different gross values of deforestation, degradation, natural recovery and improvements are derived from the analysis matrix in Table 1 based on (FAO, 2016).

Indeed, deforestation is defined by the change from "forest land" to "non-forest land". Its raw value is obtained by summing the conversions from the "forest land" category to the "cropland, other land" categories of the cells colored red in Table 1. A natural recovery class was distinguished, which made it possible to calculate a net deforestation rate by subtracting natural recovery from gross deforestation (Issifou Moumouni, 2020).

The natural recovery rate is obtained by summing the conversions of the categories "cropland" and "other land" to "forest land" colored blue in Table 1.

Gross degradation (colored yellow in Table 1), on the other hand, is obtained by the sum of transitions from the "forest land" category to the sparse (more open) "forest land" category, decreasing its capacity to produce goods and services and especially to sequester carbon (Issifou Moumouni, 2020). The transition from dense to sparse forest can sometimes involve deciduous species that lose leaf density in the dry season; this type of natural degradation is not the focus of this research because all satellite images used were taken in the dry season.

Enhancement is the conversion (colored green in Table 1) of open "forest 
Table 1. Analysis matrix for deforestation, degradation, natural recovery, and improvements.

\begin{tabular}{|c|c|c|c|c|c|c|c|c|c|c|c|}
\hline \multirow{2}{*}{ Units } & \multicolumn{5}{|c|}{ Forest Land (TF) } & \multicolumn{2}{|c|}{ Cropland (TC) } & \multicolumn{4}{|c|}{ Other Land (AT) } \\
\hline & FGFR & FD & FCSB & SASa & FSM & PT & $\mathrm{CJ}$ & $\mathrm{PE}$ & HA & SR & SED \\
\hline FGFR & S & $\mathrm{Dg}$ & $\mathrm{Dg}$ & Dg & $\mathrm{Dg}$ & $\operatorname{Re}$ & Def & Def & Def & Def & Def \\
\hline FD & $\mathrm{Am}$ & S & $\mathrm{Dg}$ & $\mathrm{Dg}$ & $\mathrm{Dg}$ & $\operatorname{Re}$ & Def & Def & Def & Def & Def \\
\hline FCSB & $\mathrm{Am}$ & $\mathrm{Am}$ & S & Dg & $\mathrm{Dg}$ & $\operatorname{Re}$ & Def & Def & Def & Def & Def \\
\hline SASa & $\mathrm{Am}$ & $\mathrm{Am}$ & $\mathrm{Am}$ & S & $\mathrm{Dg}$ & $\operatorname{Re}$ & Def & Def & Def & Def & Def \\
\hline FSM & $\mathrm{Am}$ & $\mathrm{Am}$ & $\mathrm{Am}$ & $\mathrm{Am}$ & S & $\operatorname{Re}$ & Def & Def & Def & Def & Def \\
\hline PT & $\mathrm{Rn}$ & $\mathrm{Rn}$ & $\mathrm{Rn}$ & $\mathrm{Rn}$ & $\mathrm{Rn}$ & S & $\mathrm{bBa}$ & $\mathrm{bBa}$ & $\mathrm{bBa}$ & $\mathrm{bBa}$ & $\mathrm{bBa}$ \\
\hline $\mathrm{CJ}$ & $\mathrm{Rn}$ & $\mathrm{Rn}$ & $\mathrm{Rn}$ & $\mathrm{Rn}$ & $\mathrm{Rn}$ & $\operatorname{Re}$ & S & $\mathrm{bBa}$ & $\mathrm{bBa}$ & $\mathrm{bBa}$ & $\mathrm{bBa}$ \\
\hline $\mathrm{PE}$ & $\mathrm{Rn}$ & $\mathrm{Rn}$ & $\mathrm{Rn}$ & $\mathrm{Rn}$ & $\mathrm{Rn}$ & $\operatorname{Re}$ & $\mathrm{aBa}$ & S & $\mathrm{bBa}$ & $\mathrm{bBa}$ & $\mathrm{bBa}$ \\
\hline HA & $\mathrm{Rn}$ & $\mathrm{Rn}$ & $\mathrm{Rn}$ & $\mathrm{Rn}$ & $\mathrm{Rn}$ & $\mathrm{Re}$ & $\mathrm{aBa}$ & $\mathrm{aBa}$ & $S$ & $\mathrm{bBa}$ & $\mathrm{bBa}$ \\
\hline SR & $\mathrm{Rn}$ & $\mathrm{Rn}$ & $\mathrm{Rn}$ & $\mathrm{Rn}$ & $\mathrm{Rn}$ & $\operatorname{Re}$ & $\mathrm{aBa}$ & $\mathrm{aBa}$ & $\mathrm{aBa}$ & $\mathrm{S}$ & $\mathrm{bBa}$ \\
\hline SED & $\mathrm{Rn}$ & $\mathrm{Rn}$ & $\mathrm{Rn}$ & $\mathrm{Rn}$ & $\mathrm{Rn}$ & $\operatorname{Re}$ & $\mathrm{aBa}$ & $\mathrm{aBa}$ & $\mathrm{aBa}$ & $\mathrm{aBa}$ & S \\
\hline
\end{tabular}

FD: Dense dry forest; FGFR: Gallery forest and riparian formation; FCSB: Woodland and wooded savannah; SASa: Tree and shrub savannah; FSM: Swamp forest and savannah; PT: Plantation (forest, fruit); CJ: Crop and fallow; PE: Water body; HA: Urban area; SR: Rocky surface; SED: Eroded and denuded soil.

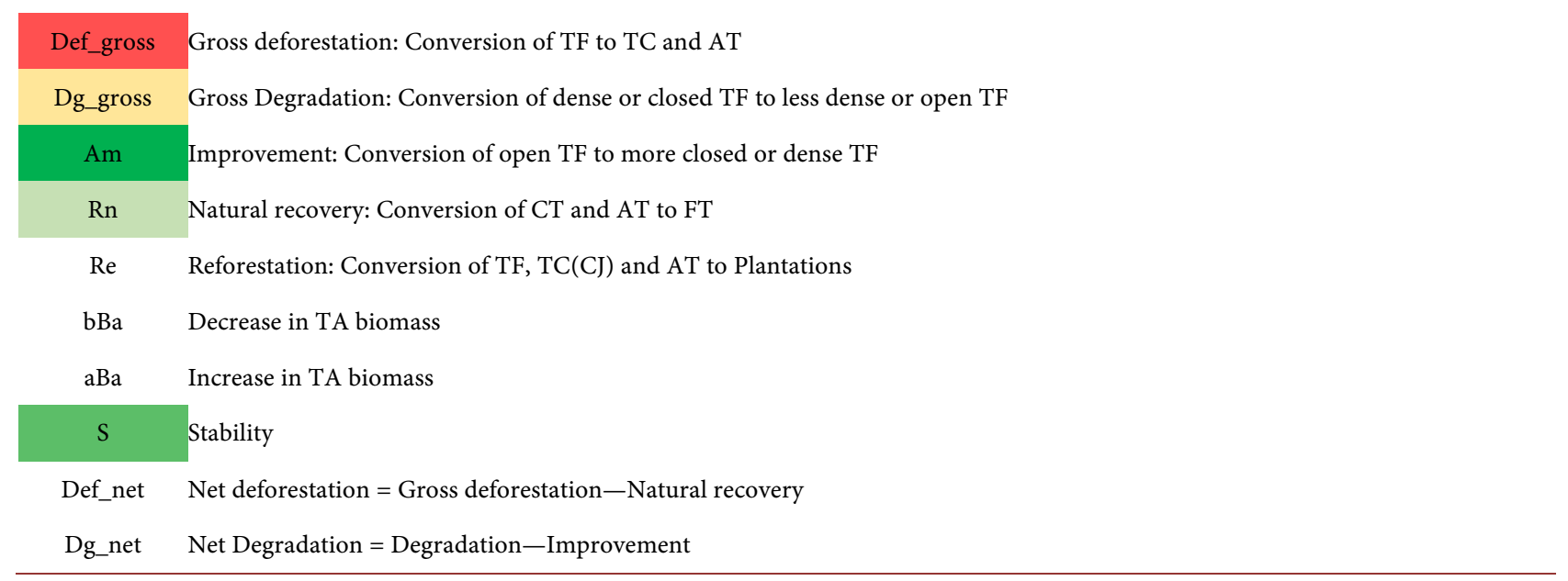

land" categories to more closed or dense "forest land" (Issifou Moumouni, 2020).

In the Benin context, afforestation refers to the establishment of forest and fruit plantations, improvement of vegetation cover and natural recovery.

Annual rates were obtained by dividing the overall deforestation rates by the number of years of study.

The overall deforestation rate $\operatorname{Tg}(D e f)$ is calculated by the following formula:

$$
\operatorname{Tg}(\text { Def })=\frac{\operatorname{Def}(b ; n) \times 100}{S 1}
$$

$\operatorname{Def}(b ; n)$ is gross $(b)$ or net $(n)$ deforestation and $S 1$ is the area of natural forest land in year $t$. 
The overall degradation rate $\operatorname{Tg}(D g)$ is calculated by the following formula:

$$
\operatorname{Tg}(D g)=\frac{D g(b ; n) \times 100}{S 1}
$$

$D g(b ; n)$ is gross $(b)$ or net $(n)$ degradation and $S 1$ is the area of natural forest land in year $t 1$.

Total uncertainty on activity data

Activity Data $(\mathrm{AD})$ are the product of the deforestation estimate (ha) from the proportions of transitions between 2000 and 2018. They combine two types of estimates: deforested areas (ha) and proportions of transition between land use classes. Both estimates are subject to various sources of error that propagate into a total error on each activity data. The error associated with each AD is estimated by following the classical error propagation rule for the product of uncertain quantities. The formula chosen in the present work is the one used by (Issifou Moumouni \& Toko Imorou, 2019) and is in the form:

$$
S(A D)=A D \times \sqrt{\left.\left(\frac{S(\hat{A})}{\hat{A}}\right)^{2}+\left(\frac{S(\text { prop })}{F C}\right)\right)^{2}}
$$

with $(A D)$ : the standard error on the $\mathrm{AD}$ of interest, $(\hat{A})$ : the standard error on the deforestation estimate, $\hat{A}$ the deforestation estimate, $S$ (prop): the standard error on the proportion of the transition of interest and prop the proportion of the transition of interest. A $95 \%$ confidence interval is calculated by multiplying $(D A)$ by the coast $\mathrm{Z}=1.96$.

\subsubsection{Methods for Determining Emission Factors (EF)}

The IPCC provides three tiers for the classification of Greenhouse Gas (GHG) emissions and removals. The tiers represent an increasing degree of expected accuracy of emission factors. The choice of which tier to use depends on the availability of data and the capacity of a country.

Tier 3 methods were adopted for estimating emission factors in this research, as their application provides estimates with greater certainty than the lower tiers (1 and 2) (Issifou Moumouni, 2020). The choice of Tier 3 requires the use of more advanced methods including models and inventory measurement systems designed for the national context, repeated over time, driven by high resolution activity data, and disaggregated at sub-national to local scales.

Emission factors are derived from assessments of carbon stock changes in the various forest carbon compartments before and after deforestation and degradation. The IPCC recognizes five carbon storage compartments: aboveground biomass, belowground biomass, litter, dead wood, and soil organic carbon. Among these compartments, aboveground woody biomass is the most studied because it is the most accessible. According to Molto (2012), it remains "the reference variable for describing the carbon stored in a forest". This is why in the context of this work it is the woody above-ground biomass that is used for the estimation of 
emission factors.

Estimation of forest biomass

Paragraph 8 of decision 12/CP.17 requires that reference emission levels be consistent with anthropogenic greenhouse gas emissions from forests. This consistency is achieved by a stratifying forest land into three phytogeographical zones for differentiation of emission factors.

Total biomass $(B)$ is the sum of aboveground $\left(B_{a}\right)$ and belowground $\left(B_{r}\right)$ biomass of all inventoried individuals.

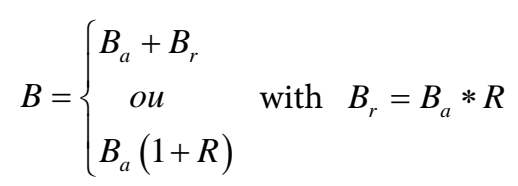

$R$ : conversion factor of aboveground biomass to belowground biomass. This factor is equal to 0.24 (Mokany et al., 2006).

Total biomass was determined by summing the total amounts of biomass obtained for each vegetation unit within each protected area. Results were presented in tons per hectare according to (GIEC, 2006) guidelines. Considering the climatic specificities of the protected areas, different allometric equations were used according to the phytogeographical zones according to the subdivision of (White, 1986).

Guineo-Congolese region

For the Lama Classified Forest, the generic pantropical model of Chave et al. (2014) was used for aboveground biomass estimation. The model has the formula:

$$
B a=0.0673 \times\left(\rho D^{2} H\right)
$$

with Ba: Aboveground biomass in $\mathrm{kg}, D$ : Diameter measured at breast height (cm), $H$ : Total height $(\mathrm{m})$, and $\rho$ : Specific gravity $\left(\mathrm{g} / \mathrm{cm}^{3}\right)$.

Sudano-Guinean transition zone

The classified forests of Monts Kouffé, Wari-Maro and Ouémé Supérieur are located in the transition zone. As a result, there is a diversity of vegetation units according to the humidity gradient. To account for this specificity in the determination of biomass, the allometric equation of Nakou (2014) was used. It is expressed by the following formula:

$$
B a=10.1859 \times 10^{-5} \times D^{2.1949} \times H^{0.5317} \times \rho^{1.3553}
$$

Bottom: aboveground biomass (ton); $D$ : diameter $(\mathrm{cm})$ measured at $1.3 \mathrm{~m}$ above ground; $H$ : total height $(\mathrm{m}) ; \rho$ : average species specific gravity $\left(\mathrm{t} / \mathrm{m}^{3}\right)$.

Sudanian region

The generic model of (Mbow et al., 2014) adapted for dry regions was used for the W Transboundary Biosphere Reserve.

This model has the formula:

$$
B a=1.929 \times D+0.116 \times D^{2}+0.013 \times D^{3}
$$

with Ba: Aboveground biomass in $\mathrm{kg}, \mathrm{D}$ : Diameter measured at breast height 
(cm).

Above-ground biomass of plantation species such as Tectona grandis L. and Anacardium occidentale $\mathrm{L}$. was calculated by multiplying the bole biomass by the Biomass Expansion Factor (BEF).

For Tectona grandis $\mathrm{L}$

The equation proposed by (Guendehou et al., 2012) was used to estimate the aboveground biomass of individuals of the species. The equation chosen is of the form:

$$
\begin{gathered}
B f=\exp [-2.1209+0.0409+2.4871 \times \ln (D)] \\
B a=B f \times B E F
\end{gathered}
$$

with $B E F=1.38$.

$B a$ aboveground biomass $(\mathrm{kg}) ; B$ : Bole biomass $(\mathrm{kg}) ; D$ : Diameter $(\mathrm{cm})$ measured at $1.3 \mathrm{~m}$ above ground level; $B E F=$ Biomass of expansion factors $(\mathrm{kg})$.

For Anacardium occidentale L

The equation of (Biah et al., 2018) was used for the estimation of aboveground biomass. The chosen equation is of the form:

$$
\begin{gathered}
B f=\exp [-1.85645+0.01656+2.02288 \times \ln (D)] \\
B a=B f \times B E F
\end{gathered}
$$

with $B E F=1.61$.

$B$ : aboveground biomass $(\mathrm{kg}) ; B$ : bole biomass $(\mathrm{kg})$; $D$ : diameter $(\mathrm{cm})$ measured at $1.3 \mathrm{~m}$ aboveground.

Estimation of $\mathrm{CO}_{2}$ Emission Factors (EF)

To calculate aboveground biomass losses due to deforestation, $\mathrm{CO}_{2}$ equivalent emission factors are calculated according to the recommendations of Chapter 2.2.1 of "GFOI Methods Guidance" for the application of the GIEC (2006) instructions in the context of REDD+ from the following equation used by (Issifou Moumouni \& Toko Imorou, 2019):

$$
E F=\left(B_{a-2005, j}-B_{a-2015, j}\right) \times F C_{(B a)} \times F C C_{\left(e q C O_{2}\right)}
$$

$E F$ : emission factors t.eq $\mathrm{CO}_{2} /$ ha;

$B a$ aboveground biomass in t.MS;

$j$ : Transition of interest;

$C F_{(B a)}$ : Carbon fraction of dry biomass equal to 0.487 proposed by (Gendehou et al., 2012).

$\mathrm{FCC}_{\left(\mathrm{CO}_{2} e q\right)}$ : Carbon to $\mathrm{CO}_{2}$ equivalent conversion factor equal to $44 / 12$.

Total uncertainty on emission factors

The standard error associated with the carbon fraction in dry biomass (FC) is 0.206 (Réjou-Méchain et al., 2017). The 95\% confidence interval around FC is therefore \pm 0.03 . Since the emission factor is the product of biomass (Ba) by FC and FCC, the uncertainty related to EFs estimated following the classical error propagation rule in the case of a product of uncertain quantities. The chosen for- 
mula is the one used by (Issifou Moumouni \& Toko Imorou, 2019) and is in the form:

$$
F_{C}=B a \times \sqrt{\left(\left(\frac{E B a}{B a}\right)^{2}+\left(\frac{E F C}{F C}\right)^{2}+\left(\frac{E F C C}{F C C}\right)^{2}\right)}
$$

with $E F C$ : error on $\mathrm{CO}_{2}$ emission factors (t.eq- $\mathrm{CO}_{2} /$ ha), $E B a$ : error on aboveground biomass $\mathrm{Ba}$ (tMS/ha), $E F C$ : error on carbon fraction in dry biomass (tMS/ha), and EFCC: error on conversion factor to $\mathrm{CO}_{2}$ equivalent (t.eq- $\mathrm{CO}_{2} / \mathrm{ha}$ ).

\subsubsection{Methods for Assessing Historical Emissions (EH) from Deforestation and Forest Degradation}

In accordance with the GIEC (2006) Good Practice Guidance on Greenhouse Gas Inventories, the calculation of historical emissions from deforestation and degradation is done by multiplying activity data (AD) by emission factors (EF).

The formula proposed by the GIEC (2006) was used to estimate historical emissions:

$$
H E=\sum_{\text {classe- } i} A D i \times E F i
$$

$H E$ : Historical Emissions in t.eq- $\mathrm{CO}_{2} ; A D$ : activity data in ha; $E F$ : emission factors in t.eq- $\mathrm{CO}_{2} /$ ha.

\subsubsection{Methods for Estimating Historical Absorptions (EH) from Afforestation}

Historical absorptions are estimated by multiplying activity data with Absorption Factors (AF). AF are the amount of carbon absorbed during natural recovery (transition from cropland to forest land), improvements (forest land remaining forest land), and reforestation.

$$
H A=\sum_{\text {classe- } i} A D i \times E F i
$$

$A H$ : Historical absorptions in t.eq- $\mathrm{CO}_{2} ; A D$ : activity data in ha; $A F$ : absorption factors in t.eq- $\mathrm{CO}_{2} /$ ha.

GHG emissions from the Agriculture, Forestry, and Other Land Use (AFOLU) sector consist of gases other than $\mathrm{CO}_{2}$, namely methane $\left(\mathrm{CH}_{4}\right)$ and nitrous oxide $\left(\mathrm{N}_{2} \mathrm{O}\right)$, generated by agricultural production, livestock, and land management activities (Issifou Moumouni \& Toko Imorou, 2019). Emissions from energy used in agriculture consist mainly of $\mathrm{CO}_{2}$ and, to a lesser extent, $\mathrm{CH}_{4}$ and $\mathrm{N}_{2} \mathrm{O}$. All emissions are expressed, for convenience and to facilitate comparison across domains, in tons of $\mathrm{CO}_{2}$ equivalents $\left(\mathrm{CO}_{2} \mathrm{e}\right)$.

The estimation of methane $\left(\mathrm{CH}_{4}\right)$ and nitrous oxide $\left(\mathrm{N}_{2} \mathrm{O}\right)$ emissions was done using $\mathrm{CO}_{2}$ equivalent. The advantage of the $\mathrm{CO}_{2}$ equivalent is that it takes into account an average of all the greenhouse gases (GHG) involved in global warming. Thus, the use of the Global Warming Potential of carbon dioxide (GWP of $\mathrm{CO}_{2}=1$ ) over a period of 100 years allowed the conversion of the amount of $\mathrm{CO}_{2}$ emitted annually into $\mathrm{CH}_{4}$ and $\mathrm{N}_{2} \mathrm{O}$. For the 100-year GWP, the ton of $\mathrm{CO}_{2}$ equivalent (t.eq- $\mathrm{CO}_{2}$ ) is equal to 1 for $\mathrm{CO}_{2}, 25$ for $\mathrm{CH}_{4}$ and 298 for 
$\mathrm{N}_{2} \mathrm{O}$ (IPCC, 2007).

$$
\begin{aligned}
& E\left(\mathrm{CH}_{4}\right)=\left(\frac{E H\left(\text { t.eq- }-\mathrm{CO}_{2}\right)}{P R G\left(\mathrm{CH}_{4}\right)}\right) \\
& E\left(\mathrm{~N}_{2} \mathrm{O}\right)=\left(\frac{E H\left(\text { t.eq }-\mathrm{CO}_{2}\right)}{P R G\left(\mathrm{~N}_{2} \mathrm{O}\right)}\right)
\end{aligned}
$$

$E\left(\mathrm{CH}_{4}\right)$ : historical methane emissions, GWP: Global Warming Potential; $E\left(\mathrm{~N}_{2} \mathrm{O}\right)$ : historical emissions of nitrous oxide;

$E H$ : historical emissions in t.eq- $\mathrm{CO}_{2}$.

\section{Results}

\subsection{Activity Data in the Studied Protected Areas}

The Activity Data $(\mathrm{AD})$ resulting from the product of the estimate of deforestation, degradation, natural recovery of forest improvement and reforestation (in ha) from the proportions of transitions between 2000 and 2018 are recorded in Table 2.

The figures in Table 2 show that the Sudano-Guinean Transition zone has a $\mathrm{CO}_{2}$ emission potential of approximately 4991.11 t.eq- $\mathrm{CO}_{2} /$ ha for an absorption potential of 574.93 t.eq- $\mathrm{CO}_{2} / \mathrm{ha}$. The Guineo-Congolese region has a potential of 360.79 t.eq- $\mathrm{CO}_{2} /$ ha of $\mathrm{CO}_{2}$ emissions, with an absorption capacity of 401.42 t.eq$\mathrm{CO}_{2} /$ ha. Finally, the Sudanian region can emit about 125.71 t.eq- $\mathrm{CO}_{2} /$ ha of $\mathrm{CO}_{2}$. The global potential of emission for all the protected areas studied is estimated at 5477.61 t.eq- $\mathrm{CO}_{2} /$ ha, against a possible absorption of 976.35 t.eq- $\mathrm{CO}_{2} /$ ha.

As a result, the $\mathrm{CO}_{2}$ emission potential is greater than the absorption potential in the Benin protected areas studied.

\begin{tabular}{|c|c|c|c|c|c|c|}
\hline Phytogeographical subdivisions & Protected areas & Activity Data & Total (ha) & $\begin{array}{c} \pm 95 \% \\
\text { IC }\end{array}$ & $\begin{array}{c}\text { Annual } \\
\text { (ha) }\end{array}$ & $\begin{array}{c}\text { Annual rate } \\
(\%)\end{array}$ \\
\hline \multirow{3}{*}{ Sudanian region } & \multirow{3}{*}{ RBTW } & Net deforestation & 8262 & 125.97 & 826.25 & 0.12 \\
\hline & & Net degradation & 11,132 & 146.22 & 1113.20 & 0.17 \\
\hline & & Afforestation & 1272 & 21.43 & 127.22 & 0.02 \\
\hline \multirow{3}{*}{$\begin{array}{l}\text { Sudano-Guinean } \\
\text { transition zone }\end{array}$} & FCMK & Net deforestation & 12,665 & 155.97 & 1266.52 & 0.26 \\
\hline & $F C W M$ & Net degradation & 20,224 & 197.09 & 2022.42 & 0.42 \\
\hline & FCOS & Afforestation & 1686 & 24.33 & 168.63 & 0.04 \\
\hline \multirow{3}{*}{ Guineo-Congolese region } & \multirow{3}{*}{ FCL } & Net deforestation & -17 & - & -1.72 & -0.05 \\
\hline & & Net degradation & 179 & 18.53 & 17.88 & 0.50 \\
\hline & & Afforestation & 18 & 1.66 & 1.81 & 0.05 \\
\hline \multirow{3}{*}{ All five protected areas } & \multirow{3}{*}{-} & Net deforestation & 20,911 & 282 & 2091 & 0.34 \\
\hline & & Net degradation & 31,535 & 18.53 & 3153 & 1.09 \\
\hline & & Afforestation & 2976 & 1.66 & 298 & 0.11 \\
\hline
\end{tabular}

Table 2. Summary of activity data in protected areas by phytogeographical regions of Benin.

RBTW: W Transboundary Biosphere Reserve; FCWM: Monts Kouffé classified forest; FCWM: Wari-Maro classified forest; FCOS: Ouémé Supérieur classified forest; IC: uncertainty. 


\section{2. $\mathrm{CO}_{2}$ Emission and Absorption Factors in Protected Areas by Phytogeographic Subdivision}

The results of the analysis of $\mathrm{CO}_{2}$ emission and absorption factors in protected areas are summarized in Table 3.

The figures in Table 3 show that the Sudano-Guinean Transition zone has a $\mathrm{CO}_{2}$ emission potential of approximately 4991.11 t.eq- $\mathrm{CO}_{2} /$ ha for an absorption potential of 574.93 t.eq- $\mathrm{CO}_{2} /$ ha. The Guineo-Congolese region has a potential of 360.79 t.eq- $\mathrm{CO}_{2} /$ ha of $\mathrm{CO}_{2}$ emissions, with an absorption capacity of 401.42 t.eq- $\mathrm{CO}_{2} /$ ha. Finally, the Sudanian region can emit about 125.71 t.eq- $\mathrm{CO}_{2} /$ ha of $\mathrm{CO}_{2}$. The global potential of emission for all the protected areas studied is estimated at 5477.61 t.eq- $\mathrm{CO}_{2} /$ ha, against a possible absorption of 976.35 t.eq- $\mathrm{CO}_{2} /$ ha.

As a result, the $\mathrm{CO}_{2}$ emission potential is greater than the absorption potential in the Benin protected areas studied.

\subsection{Historical Emissions (HE) Due to Deforestation and Forest Degradation by Phytogeographical Subdivision}

Table 4 presents the historical emissions from deforestation and forest degradation in the Benin protected areas studied.

Examination of Table 4 indicates that total $\mathrm{CO}_{2}$ emissions from deforestation are $64.25 \mathrm{Mt}$.eq $-\mathrm{CO}_{2} / \mathrm{ha}$, or $6.42 \mathrm{Mt}$.eq $-\mathrm{CO}_{2} / \mathrm{ha} /$ year. In contrast, emissions from degradation are estimated at $102.41 \mathrm{Mt}$.eq- $\mathrm{CO}_{2} / \mathrm{ha}$, or $10.24 \mathrm{Mt}$.eq- $\mathrm{CO}_{2} / \mathrm{ha} / \mathrm{yr}$. These values contain disparities at the scale of the phytogeographical subdivisions.

Indeed, at the scale of the phytogeographical subdivisions, the highest emissions due to deforestation (63.21 Mt.eq- $\mathrm{CO}_{2} / \mathrm{ha}$ ) and degradation (100.94 $\mathrm{Mt}$.eq- $\left.\mathrm{CO}_{2} / \mathrm{ha}\right)$ are noted in the Sudano-Guinean transition zone. In contrast, the Guineo-Congolese region has the lowest emissions from deforestation $(-0.01$ Mt.eq- $\mathrm{CO}_{2} /$ ha) and degradation (0.06 Mt.eq- $\mathrm{CO}_{2} / \mathrm{ha}$ ).

Overall, historical emissions from degradation are higher than those from

Table 3. Summary of $\mathrm{CO}_{2}$ emission and absorption factors by phytogeographical subdivisions.

\begin{tabular}{|c|c|c|c|c|c|}
\hline $\begin{array}{l}\text { Phytogeographical } \\
\text { subdivisions }\end{array}$ & $\begin{array}{l}\text { Protected } \\
\text { areas }\end{array}$ & $\begin{array}{c}\mathrm{EF} \\
\text { (t.éqCO } 2 / \mathrm{ha})\end{array}$ & $\pm 95 \%$ IC & $\begin{array}{c}\mathrm{AF} \\
\text { (t.éqCO } \\
2 / \mathrm{ha})\end{array}$ & $\pm 95 \%$ IC \\
\hline \multirow[t]{2}{*}{ Sudanian region } & RBTW & 125.71 & 7.34 & $\mathrm{NE}$ & $\mathrm{NE}$ \\
\hline & FCMK & & & & \\
\hline \multirow[t]{2}{*}{$\begin{array}{l}\text { Sudano-Guinean } \\
\text { transition zone }\end{array}$} & FCWM & 4991.11 & 43.48 & 574.93 & 27.38 \\
\hline & FCOS & & & & \\
\hline $\begin{array}{l}\text { Guineo-Congolese } \\
\text { region }\end{array}$ & FCL & 360.79 & 12.35 & 401.42 & 14.69 \\
\hline All five protected areas & & 5477.61 & 63.17 & 976.35 & 42.07 \\
\hline
\end{tabular}

t.eq- $\mathrm{CO}_{2}$ : ton of $\mathrm{CO}_{2}$ equivalent; ha: hectare; \pm 95 IC: uncertainty; NE: not evaluated; RBTW: W Transboundary Biosphere Reserve; FCWM: Monts Kouffé classified forest; FCWM: Wari-Maro classified forest; FCOS: Ouémé Supérieur classified forest; EF = Emission factors; AF = Absorption factors. 
Table 4. Historical net emissions from deforestation and forest degradation by phytogeographical subdivisions.

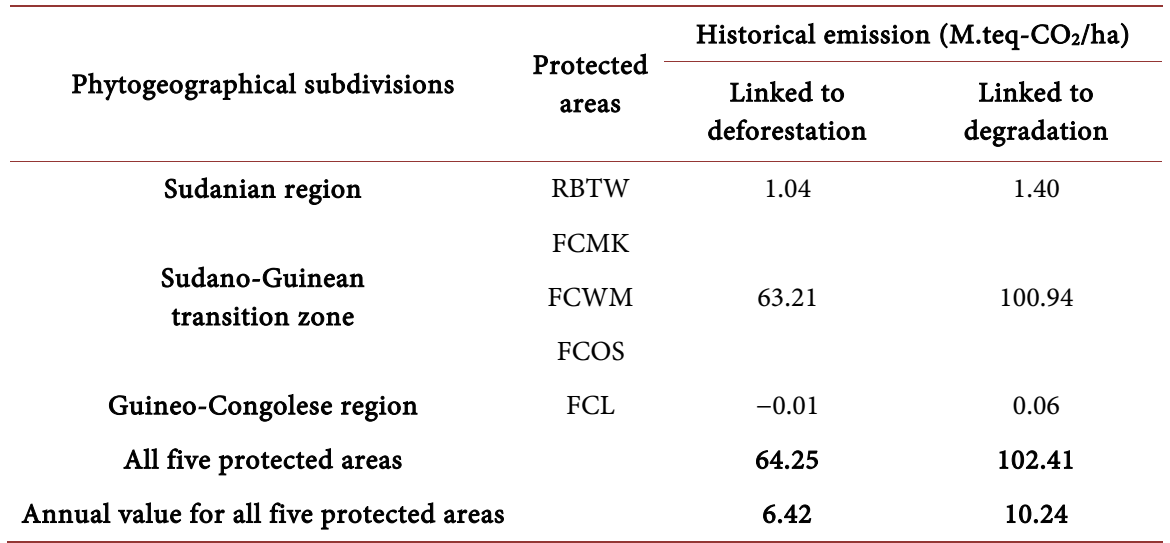

Mt.eq- $\mathrm{CO}_{2}$ : Megatonne $\mathrm{CO}_{2}$ equivalent; ha: hectare; yr: year; $\pm 95 \mathrm{CI}$ : uncertainty; RBTW: W Transboundary Biosphere Reserve; FCWM: Monts Kouffé classified forest; FCWM: Wari-Maro classified forest; FCOS: Ouémé Supérieur classified forest.

deforestation in the Benin protected areas studied.

\subsection{Baseline GHG Emissions and Absorption in the Studied Protected Areas}

Figure 2 shows the baseline emissions and absorption in the Benin protected areas studied.

The analysis of Figure 2 shows that the overall reference $\mathrm{CO}_{2}$ emissions amount to $166.65 \mathrm{Mt}$.eq- $\mathrm{CO}_{2} / \mathrm{ha}$, or $16.67 \mathrm{Mt}$.eq- $\mathrm{CO}_{2} /$ ha/year, against reference absorptions of about $1.14 \mathrm{Mt}$.eq- $\mathrm{CO}_{2} / \mathrm{ha}$, or $0.11 \mathrm{Mt}$.eq- $\mathrm{CO}_{2} / \mathrm{ha} /$ year.

At the level of the phytogeographical subdivisions, in terms of emissions, the Sudano-Guinean transition zone has the highest values with approximately 164.15 Mt.eq- $\mathrm{CO}_{2} / \mathrm{ha}$, followed by the Sudanian region with $2.44 \mathrm{Mt}$.eq- $\mathrm{CO}_{2} / \mathrm{ha}$ and finally the Guineo-Congolese region, which emits only $0.06 \mathrm{Mt}$.eq- $\mathrm{CO}_{2} / \mathrm{ha}$. The

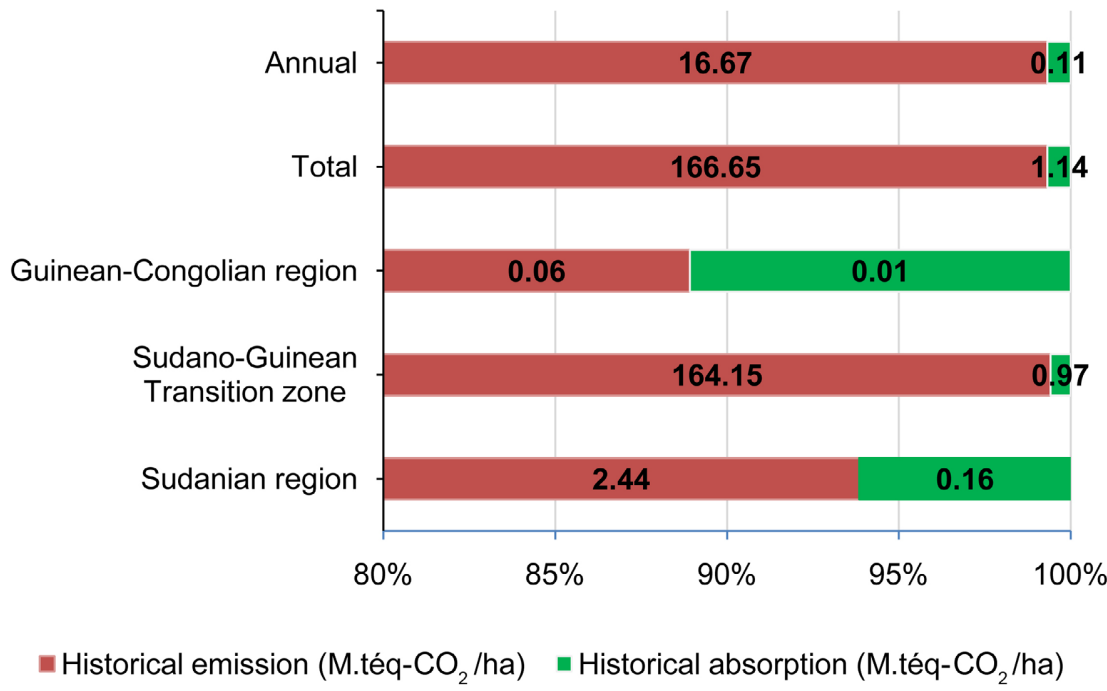

Figure 2. Baseline net emissions and absorption in the studied protected areas. 
same trends are observed for the baseline removals.

\subsection{Estimated Annual Emissions of $\mathrm{CH}_{4}$ and $\mathrm{N}_{2} \mathrm{O}$ in $\mathrm{CO}_{2}$ Equivalent}

The estimated Greenhouse Gas (GHG) emissions, namely carbon dioxide $\left(\mathrm{CO}_{2}\right)$, methane $\left(\mathrm{CH}_{4}\right)$ and nitrous oxide $\left(\mathrm{N}_{2} \mathrm{O}\right)$ are shown in Table 5. Table 5 presents the $\mathrm{CH}_{4}$ and $\mathrm{N}_{2} \mathrm{O}$ emissions in $\mathrm{CO}_{2}$ equivalent.

Apart from $\mathrm{CO}_{2}$, which is the main gas emitted in the Agriculture, Forestry and Land Use (AFOLU) sector, methane $\left(\mathrm{CH}_{4}\right)$ and nitrous oxide $\left(\mathrm{N}_{2} \mathrm{O}\right)$ are also counted as $\mathrm{CO}_{2}$ equivalents in the GHG emissions balance.

The figures in Table 5 show that the annual quantity of $\mathrm{CH}_{4}$ (0.66 Mt.eq$\left.\mathrm{CO}_{2} / \mathrm{ha} / \mathrm{yr}\right)$ and $\mathrm{N}_{2} \mathrm{O}\left(0.055 \mathrm{Mt}\right.$.eq- $\left.\mathrm{CO}_{2} / \mathrm{ha} / \mathrm{yr}\right)$ emitted is greater in the transition zone than in the other phytogeographical regions of Benin. In total, the Benin protected areas studied emit $0.67 \mathrm{Mt}$.eq- $\mathrm{CO}_{2} / \mathrm{ha} / \mathrm{yr}$ of methane annually, compared to $0.056 \mathrm{Mt}$.eq- $\mathrm{CO}_{2} / \mathrm{ha} / \mathrm{yr}$ of nitrous oxide.

Table 5. $\mathrm{CH}_{4}$ and $\mathrm{N}_{2} \mathrm{O}$ emissions in $\mathrm{CO}_{2}$ equivalent.

\begin{tabular}{cccccc}
\hline Greenhouse gas & PRG & $\begin{array}{c}\text { Sudanian } \\
\text { region }\end{array}$ & $\begin{array}{c}\text { Transition zone } \\
\text { Sudano-Guinean }\end{array}$ & $\begin{array}{c}\text { Guinean-Congolian } \\
\text { region }\end{array}$ & $\begin{array}{c}\text { All five protected } \\
\text { areas }\end{array}$ \\
\hline $\mathrm{CH}_{4}\left(\mathrm{Mt}\right.$.éq- $\left.-\mathrm{CO}_{2} / \mathrm{ha} / \mathrm{yr}\right)$ & 25 & 0.01 & 0.66 & 0.002 & 0.67 \\
$\mathrm{~N}_{2} \mathrm{O}\left(\mathrm{Mt}\right.$.éq- $\left.-\mathrm{CO}_{2} / \mathrm{ha} / \mathrm{yr}\right)$ & 298 & 0.001 & 0.055 & 0.0002 & 0.056 \\
\hline
\end{tabular}

GWP: Global Warming Potential; $\mathrm{CO}_{2}$ : Carbon Dioxide; $\mathrm{CH}_{4}$ : Methane; $\mathrm{N}_{2} \mathrm{O}$ : Nitrous oxide; $\mathrm{Mt}$.eq- $\mathrm{CO}_{2}$ : Megatonne of $\mathrm{CO}_{2}$ equivalent.

\section{Discussion}

Activity data are the areas (ha/year) moving from one land use class to another during a period of interest. In the five protected areas studied, the annual rate of deforestation is about $0.34 \%$ (or 2091 ha/year), while the annual rate of degradation is $1.09 \%$ (3153 ha). Nevertheless, we note an annual afforestation rate of $0.11 \%$ for all the protected areas studied, or $298 \mathrm{ha} /$ year. Overall, it can be deduced that the rate of degradation is greater than that of deforestation in the protected areas studied. The deforestation rate is estimated at $0.66 \%$ in the protected areas of the Benin cotton basin (Toko Imorou et al., 2018). In the OuénouBénou classified forest in northern Benin, the annual deforestation rate is $0.9 \%$ (1314.4 ha) while the degradation rate is $0.1 \%$ or 26.5 ha of the total classified forest area (Biaou et al., 2019). In Benin, in general, deforestation, which was estimated at 150,000 ha/year between 1960 and 1980, decreased from 70,000 ha/year between 1990 and 2000 to 50,000 ha/year from 2000 onwards (FAO, 2015) to $1.51 \%$ between 2005 and 2015 (Ahononga et al., 2021). It should be noted that these different values are derived from various methods of image interpretation, in this case computer-assisted visual interpretation (Ahononga et al., 2021; Issifou Moumouni, 2020) and digital interpretation (pixel-by-pixel image classification), as is the case in this research but also in the studies by (Toko Imorou et al., 2018), (Biaou et al., 2019) and FAO (2015).

In accordance with the recommendations of Chapter 2.2.1 of "GFOI Methods 
Guidance" for the application of IPCC instructions in the context of REDD+, the emission factors calculated at the scale of the protected areas studied in Benin indicate that the overall $\mathrm{CO}_{2}$ emission potential is estimated at 5477.61 t.eq- $\mathrm{CO}_{2}$, against a possible absorption of 976.35 t.eq- $\mathrm{CO}_{2}$. Overall, the $\mathrm{CO}_{2}$ emission potential is greater than the absorption potential in the protected areas studied in Benin. (Toko Imorou et al., 2018) obtained 2566.35 t.eq- $\mathrm{CO}_{2} /$ ha in the protected areas, $21,391.72$ t.eq- $\mathrm{CO}_{2} /$ ha of the Benin cotton basin. In contrast, in the Democratic Republic of Congo, the national forest monitoring system obtained about 1222.97 t.eq- $\mathrm{CO}_{2} /$ ha by assessing the baseline emission level of forests in the country (Kosa \& Muamba, 2018). These same authors in 2018 obtain 320.94 t.eq- $\mathrm{CO}_{2} /$ ha. Based on phytogeographical zones, the emission factors for dense tropical forest, dense deciduous forest and dry tropical forest zones are 534.23; 448.067 and 206.8 t.eq- $-\mathrm{CO}_{2} / \mathrm{ha}$ in Côte d'Ivoire, respectively (SEP-REDD/RCI, 2017). In the Brazilian Amazon, emission factors by vegetation type have a weighted average of $151.6 \mathrm{tC} / \mathrm{ha}$.

$\mathrm{CO}_{2}$ emissions due to deforestation amount to $64.25 \mathrm{Mt}$.eq- $\mathrm{CO}_{2} / \mathrm{ha}$, or 6.42 Mt.eq- $\mathrm{CO}_{2} / \mathrm{ha} /$ year in the Benin protected areas studied. On the other hand, emissions due to degradation are estimated at $102.41 \mathrm{Mt}$.eq- $\mathrm{CO}_{2} / \mathrm{ha}$, or 10.24 Mt.eq- $\mathrm{CO}_{2} /$ ha/year. Overall, historical emissions from degradation are higher than those from deforestation in the studied protected areas. In Ghana, emissions from deforestation in dense forests are 15,306,408 t.eq- $\mathrm{CO}_{2} / \mathrm{yr}$, while open forests emit nearly 17,640,520 t.eq- $\mathrm{CO}_{2} / \mathrm{yr}(\mathrm{FAO}, 2016)$. Historical emissions for dense tropical forests, dense deciduous forests, and dry tropical forests are 430,885,573.36 t.eq- $\mathrm{CO}_{2} / \mathrm{ha}, 460,836,752.05$ t.eq- $\mathrm{CO}_{2} /$ ha, and 32,628,325.16 t.eq$\mathrm{CO}_{2} /$ ha, respectively, in Côte d'Ivoire (SEP-REDD/RCI, 2017). Historical $\mathrm{CO}_{2}$ emissions are estimated in the protected areas of the Middle Sota Basin between 2005 and 2015 at $2.23 \mathrm{Mt}$.eq- $\mathrm{CO}_{2} / \mathrm{ha}$, or $0.02 \mathrm{Mt}$.eq- $\mathrm{CO}_{2} / \mathrm{ha} / \mathrm{year}$. The $\mathrm{CO}_{2}$ emission trajectory is an indicator for measuring the degree of disturbance of an environment. (FAO, 2016) obtains in Ghana total emissions due to deforestation of $28,487,942$ t.eq- $\mathrm{CO}_{2} /$ year. In contrast, in the DRC between 2010-2014, these emissions were estimated at $827.80 \mathrm{Mt}_{\text {eqCO}} /$ ha/year, or $2.74 \mathrm{t}$.eqCO $\mathrm{CO}_{2} / \mathrm{ha} /$ year. The Kyoto Protocol provision on natural disturbances sets the default baseline at about 800 t.eqCO $\mathrm{CO}_{2}$. Historical $\mathrm{CO}_{2}$ emissions are $23,304.17 \mathrm{t}$.eqCO $/ \mathrm{ha} / \mathrm{yr}$ in the cotton basin of Benin (Toko Imorou et al., 2018). In Côte d'Ivoire, average annual emissions are 95,330,436 t.eq- $\mathrm{CO}_{2} /$ ha (SEP-REDD/RCI, 2017). From the GHG inventory in Benin, it appears that emissions are about 7035.71 Gg.eq. $\mathrm{CO}_{2}$ for a carbon sequestration potential estimated at 5594.62 Gg.eq. $\mathrm{CO}_{2}$ in 2000 , i.e., a net emission of 1441.09 Gg.eq- $\mathrm{CO}_{2}$ (Satoguina, 2011). While Côte d'Ivoire estimates removals at 3,859,808 t.eq- $\mathrm{CO}_{2} /$ year during the period 2000-2015, in the middle Sota basin, removals due to natural recovery are of the order of 494.95 t.eq- $\mathrm{CO}_{2} / \mathrm{ha} /$ year and those related to improvements are of the order of 13,628 t.eq- $\mathrm{CO}_{2} /$ ha/year. The historical average gross emissions from forests over the period 2000-2015 in the Méau Region of southern Côte d'Ivoire are estimated to be 3,268,931 t.eq $-\mathrm{CO}_{2} / \mathrm{yr} \pm 531,654$ t.eq- $\mathrm{CO}_{2} / \mathrm{yr}$ (Ouattara, 2017). 
Overall, the studied protected areas emit $0.67 \mathrm{Mt}$.eq- $\mathrm{CO}_{2} / \mathrm{ha} / \mathrm{yr}$ of methane annually, compared to $0.056 \mathrm{Mt}$.eq- $\mathrm{CO}_{2} / \mathrm{ha} / \mathrm{yr}$ of nitrous oxide. In the middle Sota basin, according to (Issifou Moumouni \& Toko Imorou, 2019) the amount of $\mathrm{CH}_{4}$ as well as $\mathrm{N} 2 \mathrm{O}$ is 795.34 t.eq- $\mathrm{CO}_{2} / \mathrm{ha} / \mathrm{yr}$ and 84.04 t.eq- $-\mathrm{CO}_{2} / \mathrm{ha} / \mathrm{yr}$ in protected areas. (Toko Imorou et al., 2018) estimated these two gases at 59,026.03 t.eq- $\mathrm{CO}_{2} / \mathrm{ha} / \mathrm{yr}$ and $795,568.16$ t.eq- $\mathrm{CO}_{2} / \mathrm{ha} / \mathrm{yr}$ respectively in protected areas in northeast Benin.

\section{Conclusion}

The estimation of baseline emissions and removals due to deforestation and degradation in the protected areas studied in Benin has made it possible to highlight the impacts of deforestation and forest degradation phenomena on the climate in the context of global change. The direct impact of deforestation and degradation is the high rate of $\mathrm{CO}_{2}$ emission recorded in the 18-year interval. Overall, the rate of degradation is greater than that of deforestation in the five protected areas in the study. It is also noted that the potential for GHG emissions is greater than that of absorption. The consequence of these results is that historical emissions due to degradation are greater than those due to deforestation in Benin's protected areas. To make matters worse, GHG emissions are higher than GHG removals in the protected areas studied.

It is therefore clear that actions to mitigate GHG emissions must be undertaken directly in Benin's protected areas to safeguard what can still be safeguarded in order to achieve the 2025 vision of the national forest policy, which aims to make Benin a green country where forest, wildlife and natural resources are managed sustainably to meet the ecological, economic and socio-cultural needs of the population and contribute to poverty reduction, food security and the fight against climate change.

The main contribution of this research is the knowledge of the reference emission and absorption levels of greenhouse gases in the protected areas of Benin.

The innovation of the research is expressed here in terms of technical achievements resulting from the study. The technical achievements resulting from this work are:

1) New approaches for estimating baseline emission and absorption levels for forests;

2) Forest biomass and carbon estimation techniques;

3) Forest biomass spatialization techniques;

4) Carbon spatialization techniques.

\section{Recommendations}

At the end of this research, it is appropriate to make some recommendations to the various actors to enable Benin to fully meet its international commitments in order to contribute effectively to the mitigation of global warming.

In view of the interesting results obtained in the framework of this work, it is appropriate to:

- Extend the estimation of the reference emission level of forests to all pro- 
tected areas of the country with the same approach;

- Conduct another large-scale forest inventory to obtain reliable data. These data on above-ground biomass and dead wood will make it possible to refine the FREL/FRL in the short term;

- Work towards the availability of national scale mapping data over a period of 10 years, using satellite data (e.g. MODIS data: burn area; LiDAR) on a national scale could allow the consideration of gases other than $\mathrm{CO}_{2}$. This includes $\mathrm{CH}_{4}$ from vegetation fires that are very recurrent in the northern half of the country during the dry season.

To reduce the pressure on forests within protected areas, several recommendations were made by the populations to the communal authorities and the government, including:

- Supporting young people in the creation of micro-projects and businesses;

- Strengthening the promotion of income-generating activities other than agriculture;

- Financing studies on the search for innovative solutions to land degradation problems;

- Promoting village nurseries to support reforestation;

- Promoting communal and community plantations and forests as well as private plantations;

- Promoting renewable energies, especially solar and biogas, to reduce pressure on wood energy;

- Promoting sustainable land management techniques and adaptation to climate change;

- Regulating forestry exploitation;

- Promoting climate-smart agriculture.

\section{Acknowledgements}

Sincere gratitude to the National Fund for Scientific Research and Technological Innovation (FNRSIT) of the Ministry of Higher Education and Scientific Research (MESRS), which financed the present research $\mathrm{N}^{\circ}$ 006/MESRS/FNRSIT/AC/SSE/SAI/SA du 21/07/17, as well as to all the partner laboratories and institutions that made it possible to achieve the objectives of the study through their material and methodological contribution.

\section{Conflicts of Interest}

The authors declare no conflicts of interest regarding the publication of this paper.

\section{References}

Ago, E. E. (2016). Dynamique des flux de carbone entre l'atmosphere et des écosystèmes ouest-africains: Cas des forêts et savanes sous climat soudanien au Benin (184 p). Thèse de Doctorat en Sciences Agronomiques et Ingénierie Biologique, Fédération WallonieBruxelles Académie Universitaire Wallonie-Europe Université De Liège Gembloux Agro Bio Tech. 
Ahononga, F.C., Awessou, B. K., Kouton, M. D., Plagbeto, H. A., Orékan, O. V., Toko Imorou, I., Pinet, C., \& Mertens, B. (2021). Atlas cartographique de la dynamique de l'occupation du sol au Bénin entre 2005 et 2015 (338 p). Dépôt légal N 12881 du 09/02/2021. Bibliothèque Nationale du Bénin. 1er trimester.

Biah, I., Guendehou, S., Goussanou, C., Kaire, M., \& Sinsin, A. B. (2018). Allometric Models for Estimating Biomass Stocks in Cashew (Anacardium occidentale L.) Plantation in Benin. Bulletin de la Recherche Agronomique du Bénin (BRAB), Numéro 84, 16-27.

Biaou, S., Houeto, F., Gouwakinnou, G., Biaou, S. S. H., Awessou, B., Tovihessi, S., \& Tete R. (2019). Dynamique spatio-temporelle de l'occupation du sol de la forêt classée de Ouénou-Bénou au Nord Bénin. Conférence OSFACO: Des images satellites pour la gestion durable des territoires en Afrique, Cotonou, Mar 2019, hal-02189367.

CEDEAO (Economic Community of West African States) (2015). Evaluation des ressources forestières dans l'espace CEDEAO: Stratégies REED+ dans la gestion des ressources forestières. Rapport provisoire. Economic Community of West African States.

CENATEL (2013). Les changements d'occupation des terres au Bénin, Science for a Changing World (USGS) (8 p).

Chave, J., Mechain, M. R., Burquez, A., Chidumayo, E., Colgan, M. S., Delitti, W. B. C., Duque, A., Eid, T., Fearnside, P. M., Goodman, R. C., Henry, M., Martinez-Yrizar, A., Mugasha, W. A., Muller-Landau, H. C., Mencuccini, M., Nelson, B. W., Ngomanda, A., Nogueira, E. M., Ortiz-Malavassi, E., Pelissier, R., Ploton, P., Ryan, C. M., Saldarriaga, J. G., \& Vieilledent, G. (2014). Improved Allometric Models to Estimate the Aboveground Biomass of Tropical Trees. Global Change Biology, 20, 3177-3190. https://doi.org/10.1111/gcb.12629

FAO (Food and Agriculture Organization) (2015). Evaluation des ressources forestières mondiales 2015: Rapport national du Bénin (37 p). Food and Agriculture Organization.

FAO (Food and Agriculture Organization) (2016). Considérations techniques relatives à l'établissement de niveaux d'émissions de référence pour les forêts et/ou niveaux de référence pour les forêts dans le contexte de la REDD+ au titre de la CCNUCC. Programme ONU-REDD.

http://www.unredd.net/index.php?option=com docman\&task=doc download\&gid=13 $\underline{4698 \text { Itemid }=53}$

GIEC (Institute for Global Environmental Strategies) (2006). Lignes directrices $2006 \mathrm{du}$ GIEC pour les inventaires nationaux de gaz à effet de serre, préparé par le Programme pour les inventaires nationaux de gaz à effet de serre. Eggleston, H.S., Buendia, L., Miwa, K., Ngara, T., \& Tanabe, K. (Eds.), Institute for Global Environmental Strategies.

Guendehou, G. H. S., Lehtonen, A., Moudachirou, M., Mäkipää, R., \& Sinsin, B. (2012). Stem Biomass and Volume Models of Selected Tropical Tree Species in West Africa. Southern Forests, 74, 77-88. https://doi.org/10.2989/20702620.2012.701432

Herzog, T. (2005). World Greenhouse Gas Emissions in 2005 (5 p). WRI Working Paper. World Resources Institute.

IFN (2007). Exécution d'un Inventaire Forestier National (IFN): Traitement et analyse des données LANDSAT 7 ETM+. Elaboration de la carte forestière par V. O. A. OREKAN. Projet Bois De Feu—Phase II (61 p). Direction Des Forêts Et Des Ressources Naturelles, Bénin.

IPCC (Intergovernmental Panel on Climate Change) (2007). Special Report to Decision Makers 2007 (No. 15, pp. 5-90). Special Report, IPCC (Intergovernmental Panel on Climate Change), UNEP (United Nations Environment Programme).

IPCC (Intergovernmental Panel on Climate Change) (2019). Refinement to the 2006 IPCC Guidelines for National Greenhouse Gas Inventories. Intergovernmental Panel on Climate Change. 
Issifou Moumouni, Y. (2020). Evaluation de la Déforestation et de la Dégradation du couvert végétal et estimation des Gaz à Effet de Serre correspondants dans le Bassin moyen de la Sota au Nord-Bénin (284 p). Thèse de Doctorat, Université d'Abomey-Calavi.

Issifou Moumouni, Y., \& Toko Imorou, I. (2019). Estimation des émissions dues à la déforestation dans le bassin moyen de la Sota (Nord-Bénin). des CAHIERS DE L'ACAREF, 1, 394-408.

Kosa, V., \& Muamba, M. (2018). Construction du niveau d'émission de référence des forets de la république démocratique du Congo. Conférence OSFACO: Des images satellites pour la gestion durable des territoires en Afrique, Cotonou, Mar 2019, hal-02189434

Marquant, B., Mosnier, A., Bodin, B., Dessard, H., Feintrenie, L., Molto, Q. et al. (2015). Importance des forêts d'Afrique centrale.

Mbow, C., Verstraete, M. M., Sambou, B., Diaw, A. T., \& Neufeldt, H. (2014). Allometric Models for Aboveground Biomass in Dry Savanna Trees of the Sudan and Sudan-Guinean Ecosystems of Southern Senegal. Journal of Forest Research, 19, 340-347. https://doi.org/10.1007/s10310-013-0414-1

Mokany, K., Raison, R. J., \& Prokushkin, A. S. (2006). Critical Analysis of Root: Shoot Ratios in Terrestrial Biomes. Global Change Biology, 12, 84-96. https://doi.org/10.1111/j.1365-2486.2005.001043.x

Molto, Q. (2012). Estimation de biomasse en forêt tropicale humide: Propagation des incertitudes dans la modélisation de la distribution spatiale de la biomasse en Guyane française. Université des Antilles et de la Guyane (184 p). Thèse de Doctorat en physiologie et biologie des organismes, populations, interactions de la Faculté des sciences exactes de l'Université des Antilles et de la Guyane.

Nakou, L. G. K. (2014). Développement des équations allométriques pour l'estimation de la biomasse aérienne des arbres en zone soudano-guinéenne au Bénin (73 p). Mémoire de Master, Université d'Abomey-Calavi.

Ouattara, T. A. (2017). Niveau d'émission de référence pour les forêts de la Région de la Mé, Etc Terra Rongead (28 p).

Réjou-Méchain M., Tanguy A., Piponiot C., Chave J., and Hérault B. (2017). Application Biomass: An R Package for Estimating Above-Ground Biomass and Its Uncertainty in Tropical Forests Methods. Ecology and Evolution, 8, 1163-1167.

https://doi.org/10.1111/2041-210X.12753

Satoguina H. (2011). Scénarios d'atténuation des changements climatiques au Bénin. Revue d'Economie Théorique et Appliquée, 1, 105-118.

SEP-REDD/RCI (République de la Côte d'Ivoire) (2017). Niveau d'Emissions de Référence pour les Forêts de la Côte d'Ivoire (50 p). Présentation à la Convention Cadre des Nations Unies pour le Changement Climatique.

Toko Imorou, I., Arouna, O., Zakari, S., Djaouga, M., \& Thomas, O. (2018). Évaluation de la déforestation et de la dégradation des forêts dans les aires protégées et terroirs villageois du bassin cotonnier du Bénin. Conférence OSFACO: Des images satellites pour la gestion durable des territoires en Afrique, Cotonou, Mar 2019, 26.

White, F. (1986). La végétation d'Afrique. Mémoire accompagnant la carte de la végétation d'Afrique (391 p). United Nations Educational, Scientific and Cultural Organization/Association pour l'Etude Taxonomique de la Flore d'Afrique Tropicale/United Nations Soudano-Sahelian Office, Office de la Recherche Scientifique et Technique d'Outre-MerUnited Nations Educational, Scientific and Cultural Organization. 